\title{
ZNACZENIE ZASADY IGNORANTIA IURIS NOCET W POLSKIM POSTĘPOWANIU ADMINISTRACYJNYM OCENA PROBLEMU POD KĄTEM ORZECZNICTWA SĄDOWO- -ADMINISTRACYJNEGO
}

\section{Wprowadzenie}

Przyjmuje się powszechnie obowiązywanie $\mathrm{w}$ polskim systemie prawnym zasad wynikających z prawa rzymskiego. Jedną z nich jest znana zasada ignorantia iuris nocet (nieznajomość prawa szkodzi). Należy się jednak zastanowić nad znaczeniem tej zasady w polskim postępowaniu administracyjnym, czyli ustalić, czy w ramach tych regulacji jest lub może być stosowana - a jeżeli tak to w jakim zakresie - czy też nie powinna być ona stosowana $\mathrm{w}$ ogóle. Niezbędne jest zatem ustalenie granic zasady ignorantia iuris nocet $\mathrm{w}$ ramach postępowania administracyjnego, przy czym trzeba się odwołać do podstawowych zasad nim rządzących, w szczególności do zasady informowania stron i innych uczestników postępowania. Ocena tego problemu powinna przede wszystkim odbyć się na podstawie orzecznictwa sądów administracyjnych, gdyż ono na przestrzeni lat niekiedy znacznie ewoluuje. Ma to o tyle doniosłe znaczenie, że ustawa z dnia 14 czerwca 1960 r. - Kodeks postępowania administracyjnego ${ }^{1}$ obowiązuje już przeszło pół wieku i nawet pomimo zmian redakcyjnych niewiele się zmieniła od chwili jej wejścia w życie. Ponadto orzeczenia sądowe zapadają w konkretnych sprawach, a zatem podjęcie problemu następuje w różnych stanach faktycznych. Orzecznictwo sądowo-administracyjne pomimo tego, że nie stanowi źródła prawa

\footnotetext{
* Mgr, absolwent prawa Kujawsko-Pomorskiej Szkoły Wyższej w Bydgoszczy.

${ }^{1}$ Ustawa z dnia 14 czerwca 1960 r. - Kodeks postępowania administracyjnego, Dz. U. z 2017 r. poz. 1257 z późn. zm. (dalej KPA).
} 
ani wykładnia przedstawiona w tych orzeczeniach dla organów administracji publicznej nie jest wiążąca, to jednak znacząco wpływa na praktykę stosowania prawa. Z tych właśnie względów należy przynajmniej podjać rozważania na temat obowiązywania zasady ignorantia iuris nocet $\mathrm{w}$ ramach procedury administracyjnej pod kątem orzecznictwa sądowoadministracyjnego. I choć przedmiotem analizy w dalszej części będzie dorobek judykatury, warto również - w tytułem zasygnalizowania przywołać stanowisko doktryny.

\section{Zasada ignorantia iuris nocet}

Podjęcie podstawowej kwestii związanej z zagadnieniem będącym tematem niniejszego opracowania należy rozpocząć od przybliżenia znaczenia łacińskiej paremii ignorantia iuris nocet, a właściwie ignorantia iuris nocet, facti non nocet, czyli nieznajomość prawa szkodzi, nieznajomość faktu nie szkodzi. Paremia ignorantia iuris nocet pochodzi jeszcze z prawa rzymskiego. Z treści tej zasady wynika swoistego rodzaju podział na błędy co do prawa oraz błędy co do faktów oraz to, że podmiotom prawa szkodzą tylko te pierwsze. Wynika z tego, że podmiot prawa nie może się tłumaczyć ze swoich działań albo zaniechań w związku z tym, iż nie znał treści norm prawnych ${ }^{2}$. Na potrzeby niniejszej pracy istotna jest właśnie ta część wspomnianej zasady odnosząca się do prawa. Oczywiście należy wyraźnie podkreślić, że zasada ignorantia iuris nocet $\mathrm{w}$ aktualnym stanie prawnym może mieć wyłącznie zastosowanie do norm prawnych wynikających z obowiązujących i odpowiednio ogłoszonych aktów prawnych. Niezwykle istotne znaczenie ma fakt ogłaszania aktów prawnych, gdyż dopiero $\mathrm{z}$ tą chwilą ich adresaci mają możliwość zapoznania się z treścią norm ich dotyczących, a zatem stosownie do przedmiotowej zasady dopiero $\mathrm{z}$ tą chwilą nie mogą się oni zasłaniać nieznajomością prawa. Z oczywistych względów nawet możliwość zaznajomienia się z treścią przepisów prawnych nie powoduje, że ich adresaci znają swoje prawa i obowiązki, gdyż wynika to głównie z indywidualnych cech i ich przygotowania do interpretowania norm, które nie zawsze są precyzyjne i zrozumiałe. Stąd też ze względu na zasady współżycia społecznego,

${ }^{2}$ Wyrok TK z dnia 12 listopada 2001 r., P 2/01, LEX 2016. 
czy inne uzasadnione przyczyny, należy posługiwać się zasadą ignorantia iuris nocet w sposób ostrożny - tym bardziej, że w polskim prawie nie wynika ona bezpośrednio z norm prawnych, w szczególności tych będących zasadami.

\section{Zasada informowania stron i innych uczestników postępowania (art. $9 \mathrm{KPA})$}

Kodeks postępowania administracyjnego w Dziale I, Rozdział 2, art. 6-16 zawiera ogólne zasady postępowania. Wśród tych zasad ustawodawca wymienia: zasadę praworządności (art. $6 \mathrm{KPA}$ ), zasadę prawdy obiektywnej (art. $7 \mathrm{KPA})$, zasadę rozstrzygania wątpliwości na korzyść strony (art. 7a KPA), zasadę współdziałania organów administracji publicznej (art. 7b KPA), zasadę pogłębiania zaufania obywateli i utrwalonych praktyk rozstrzygania spraw (art. $8 \mathrm{KPA}$ ), zasadę informowania stron i innych uczestników postępowania (art. $9 \mathrm{KPA}$ - dalej jako zasada informowania stron), zasadę czynnego udziału strony w postępowaniu (art. $10 \mathrm{KPA})$, zasadę przekonywania (art. $11 \mathrm{KPA}$ ), zasadę szybkości i prostoty postępowania (art. $12 \mathrm{KPA}$ ), zasadę ugodowego załatwiania spraw (art. $13 \mathrm{KPA}$ ), zasadę pisemności (art. $14 \mathrm{KPA}$ ), zasadę dwuinstancyjności postępowania (art. $15 \mathrm{KPA}$ ) oraz zasadę trwałości decyzji (art. $16 \mathrm{KPA}$ ). Dla potrzeb niniejszego artykułu najważniejsze znaczenie ma zasada informowania stron, jednak ze względu na powiązanie tej zasady z innymi należało wymienić je wszystkie. Zasada informowania stron wynika z art. 9 KPA, który stanowi, że organy administracji publicznej zobowiązane są do należytego i wyczerpującego informowania stron o wszelkich okolicznościach prawnych i faktycznych, które mogą mieć wpływ na ich prawa i obowiązki będące przedmiotem postępowania, a ponadto wspomniane organy zobowiązane są czuwać nad tym, aby strony oraz inni uczestnicy postępowania nie ponieśli szkody z powodu nieznajomości prawa, i w tym celu powinny udzielać im niezbędnych wyjaśnień i wskazówek. Już sama treść zasady informowania stron wskazuje na jakiś związek z zasadą ignorantia iuris nocet, jednak relacje obu tych zasad zostaną przedstawione w dalszej części. Zasada informowania stron głównie skierowana jest do organów administracji publicznej prowadzących postępowanie administracyjne, stąd też przyjmuje się, że powinna być ona rozpatrywana w trzech płaszczyznach: 
czasowej, podmiotowej i przedmiotowej ${ }^{3}$. Zakres czasowy polega na tym, że zasada $\mathrm{z}$ art. $9 \mathrm{KPA}$ obowiązuje $\mathrm{w}$ granicach prowadzonego postępowania ${ }^{4}$. Zakres podmiotowy dotyczy podmiotów, do których przedmiotowy przepis jest skierowany, czyli do tych zobowiązanych do udzielania informacji oraz do tych uprawnionych do jej uzyskania. Podmiotem zobowiązanym do udzielenia informacji zawsze będzie organ administracji publicznej, zarówno ten prowadzący postępowanie główne, ten współdziałający, jak również ten działający w ramach pomocy prawnej5. Natomiast uprawnionymi do uzyskania informacji zawsze będą strony postępowania oraz inni uczestnicy, z tym jednak zastrzeżeniem, że w przypadku stron organ zobowiązany jest udzielać informacji o charakterze faktycznym i prawnym, a wobec pozostałych uczestników wyłącznie wskazówek natury prawnej w celu zapobieżenia szkody z powodu nieznajomości prawa ${ }^{6}$. Zakres przedmiotowy odnosi się do prawa do informacji, które powinno być realizowane $\mathrm{w}$ różny sposób wobec podmiotów profesjonalnych i podmiotów nieprofesjonalnych? ${ }^{7}$.

Zasada informowania stron jest realizowana również na podstawie przepisów szczególnych dotyczących postępowania administracyjnego, a mianowicie choćby poprzez obowiązek dokonywania przez organ w decyzji uzasadnienia faktycznego i prawnego, czy pouczania stron o możliwości zaskarżenia aktu administracyjnego. Warto zwrócić uwagę, że zasada informowania stron ma związek $\mathrm{z}$ innymi zasadami postępowania i tym samym można przyjąć, że pełni ona rolę subsydiarną wobec innych zasad, gdyż bez niej niektóre $\mathrm{z}$ nich nie mogłyby zostać $\mathrm{w}$ pełni zrealizowane. Wśród tych zasad, z którymi zasada informowania stron ma związek, z całą pewnością należy wymienić: zasadę prawdy obiektywnej, zasadę pobudzania zaufania obywateli ${ }^{8}$, zasadę czynnego udziału strony ${ }^{9}$, zasadę przekonywania, czy też zasadę ugodowego załatwiania spraw. Obowiązek informowania stron w zakresie dotyczącym prawa odnosi się zarówno do przepisów prawa materialnego, jak i procesowego. Ma to przede wszystkim na celu uchronienie stron przed celowym dzia-

${ }^{3}$ H. Knysiak-Molczyk (red.), Kodeks postępowania administracyjnego. Komentarz, LEX 2016, komentarz do art. 9.

${ }^{4}$ Wyrok NSA z dnia 2 marca 2012 r., II OSK 2464/10, LEX 2016.

${ }^{5}$ H. Knysiak-Molczyk (red.), Kodeks..., LEX 2016, komentarz do art. 9.

6 Tamże.

7 Tamże.

8 Wyrok WSA w Gliwicach z dnia 29 czerwca 2016 r., IV SA/Gl 1056/15, LEX 2016.

9 Wyrok NSA z dnia 19 marca 2015 r., II OSK 1985/13, LEX 2016. 
łaniem organów administracji publicznej, które mogłyby dążyć do tego, aby strony nie korzystały ze swoich uprawnień, a tym samym ponosiłyby $\mathrm{z}$ tego powodu szkodę ${ }^{10}$.

\section{Relacja między zasadą ignorantia iuris nocet a zasadą informowania stron (art. 9 KPA) - stanowiska sądów administracyjnych}

Z powyższych ustaleń wynika, że istnieje wyraźna relacja między rzymską zasadą ignorantia iuris nocet a zasadą informowania stron wynikającą z art. 9 KPA. Wyrazistość tej relacji polega na tym, że obie zasady odnoszą się do pojęcia „nieznajomości prawa”. Pierwsza wprost przewiduje konsekwencje związane z nieznajomością prawa, natomiast druga (szczególnie w drugiej części art. 9 KPA) przewiduje obowiązki organów dotyczące tego, aby strony postępowania nie ponosiły konsekwencji związanych z nieznajomością prawa. Stąd można wyciągnąć wniosek, że relacja przedmiotowych zasad ma charakter przeciwstawny, czyli w pierwszym odczuciu można przyjąć, że zasada z art. 9 KPA wyłącza w ramach procedury administracyjnej obowiązywanie zasady ignorantia iuris nocet, która de facto nie wynika z jakichkolwiek norm prawnych. Rzeczywiście $\mathrm{w}$ orzecznictwie sądowo-administracyjnym tego typu pogląd dominuje $\mathrm{e}^{11}$. Zasadniczo rygorystyczne stanowisko (przyjęte $\mathrm{z}$ aprobatą przez wielu przedstawicieli doktryny ) w zakresie stosowania zasady ignorantia iuris nocet $\mathrm{w}$ ramach prawa administracyjnego, $\mathrm{w}$ tym $\mathrm{w}$ ramach procedury administracyjnej, zaprezentowała również Z. Duniewska. Autorka przeprowadziła szczegółową analizę przedmiotowego zagadnienia i wskazała, że charakter prawa administracyjnego nie pozwala na włączenie do niego $\mathrm{w}$ tradycyjnym, niewzruszonym rozumieniu, fikcji powszechnej znajomości prawa oraz wynikającej z niej zasady ignorantia iuris nocet ${ }^{12}$. Ponadto Z. Duniewska podkreśliła „bezwzględną potrzebę uwzględnienia szeregu przesłanek usprawiedliwiających nieznajomość prawa i wynikłe

${ }^{10}$ Wyrok WSA w Poznaniu z dnia 8 marca 2007 r., IV SA/Po 516/06, LEX 2016; Wyrok WSA w Warszawie z dnia 18 marca 2013 r., I SA/Wa 2169/12, LEX 2016.

${ }_{11}$ Zob. H. Knysiak-Molczyk (red.), Kodeks..., komentarz do art. 9; oraz wskazane tam orzecznictwo.

12 Zob. Z. Duniewska, Ignorantia iuris w prawie administracyjnym, Łódź 1998, s. 215. 
z niej niezastosowanie się do jego norm. Zaistnienie tych przesłanek implikować powinno wyłączenie bądź ograniczenie zarzucalności prawnej ignorancji prawa administracyjnego, a ściślej - zarzucalności nieuwzględnienia z tej przyczyny wiążących obywatela norm prawnych"13. Należy się jednak zastanowić, czy pogląd w zaprezentowanej wyżej kwestii powinien być aż tak rygorystyczny. Dla rozstrzygnięcia tego problemu niezbędne jest ustalenie granic obowiązywania zasady ignorantia iuris nocet $\mathrm{w}$ polskim postępowaniu administracyjnym. Do ustalenia tych granic niezwykle przydatne są te orzeczenia sądów administracyjnych, które stanowią wyłom od powyższego poglądu zakładającego całkowite wyłączenie zasady ignorantia iuris nocet - czy też jej złagodzenie. Występują takie orzeczenia sądów administracyjnych, które zakładają że pomimo zasady informowania stron rzymska zasada nadal obowiązuje. Najczęściej dotyczy to podmiotów profesjonalnych to jest: adwokatów, radców prawnych ${ }^{14}$, ale także podmiotów prowadzących działalność gospodarczą. Sądy stoją na stanowisku, że od takich podmiotów należy wymagać więcej, gdyż posiadają one większą wiedzę prawniczą oraz w ramach swoich działań powinny dochować należytej staranności ${ }^{15}$. Natomiast w stosunku do podmiotów nieprofesjonalnych zasada informowania stron powinna mieć charakter bardziej rygorystyczny ${ }^{16}$. Nie oznacza to, jednak, że organy administracji publicznej $\mathrm{w}$ ramach prowadzonego postępowania powinny takim podmiotom udzielać jakiejś formy doradztwa prawnego, czy też wskazywać optymalny sposób postępowania albo informować o treści opublikowanych aktów prawnych ${ }^{17}$. Wreszcie niekiedy nadmierne informowanie jednej ze stron postępowania o przysługujących jej prawach które z kolei mogą ograniczyć prawa innych stron - może być poczytywane jako naruszenie innych zasad ${ }^{18}$. W takim przypadku w szczególności może dojść do naruszenia zasady prawdy obiektywnej, zasady pobudzania zaufania, czy też zasady ugodowego załatwiania spraw. W związku z tym należy przyjąć, że współistnienie zasady z art. 9 KPA nie tylko ma charakter uzupełniający, ale niekiedy wręcz wyłączający, co wymaga od

13 Tamże, s. 216.

${ }^{14}$ Wyrok NSA z dnia 16 maja 2012 r., I OSK 699/11, LEX 2016.

15 Postanowienie WSA w Warszawie z dnia 18 lutego 2016 r., VI SA/Wa 1542/15, LEX 2016.

${ }^{16}$ Wyrok WSA w Łodzi z dnia 13 marca 2014 r., III SA/Łd 1306/13, LEX 2016.

17 Wyrok NSA z dnia 4 sierpnia 2016 r., I OSK 2598/14, LEX 2016; Wyrok NSA z dnia 20 listopada 2012 r., II OSK 1301/11, LEX 2016.

18 Wyrok NSA z dnia 17 czerwca 2011 r., II OSK 1102/10, LEX 2016. 
organu w konkretnym przypadku wyważenia, która z zasad postępowania jest ważniejsza. W takiej sytuacji organ musi przynajmniej dochować zasady informowania dla każdej ze stron co najmniej na takim samym poziomie, ale jednocześnie dbać, aby żadna ze stron nie poniosła $\mathrm{z}$ tego tytułu szkody w związku z nieznajomością prawa, co jest niezwykle trudne w sytuacji, kiedy w danym postępowaniu występują strony zarówno profesjonalne, jak i nieprofesjonalne.

Wreszcie wymaga zastanowienia sytuacja, w której w postępowaniu występuje strona nieprofesjonalna, która $\mathrm{w}$ jakimś zakresie posiada wiedzę na temat swoich praw i obowiązków związanych z tym postępowaniem. W takim przypadku to strona może wyczekiwać na błąd proceduralny organu, a niekiedy nawet wymuszać taki błąd. Trzeba by się zastanowić, czy w takim przypadku można mówić o poniesieniu szkody przez stronę w związku z nieznajomością prawa. Skoro taka strona z premedytacją wykorzystuje błąd organu i wiedziała o takim błędzie, to przecież trudno mówić o nieznajomości prawa, szczególnie, jeśli następnie wykorzystuje go jako uzasadnienie zaskarżenia jakiejś czynności organu. Ponad to nawet, jeżeli strona w przedstawionym stanie faktycznym nie ma świadomości prawnej na temat błędów popełnionych przez organ w ramach postępowania, a w chwili wnoszenia na przykład odwołania była w stanie uzyskać wiedzę na ten temat, to czy w takiej sytuacji nie powinno się przyjąć, że obowiązywała zasada ignorantia iuris nocet. Dzisiaj w dobie Internetu świadomość prawna społeczeństwa jest większa, albo inaczejmożliwość uzyskania jakiejś wiedzy jest szersza. W związku z tym problem stosowania zasady informowania stron należy również rozpatrywać pod tym kątem - nie jako samej „nieznajomości prawa”, ale może raczej dosłownie jako „ignorancji wobec prawa”. Słowo „ignorancja” jest tutaj dosyć kluczowe, gdyż można je tłumaczyć nie tylko jako „nieznajomość”, ale także jako „nieuctwo" ${ }^{19}$ - czyli nie tylko brak wiedzy, ale także niechęć do jej zdobywania. Może w tym kontekście w aktualnym stanie prawnym należałoby rozumieć zasadę ignorantia iuris nocet. W związku z tym zasada ignorantia iuris nocet obowiązy wałaby w ramach procedury administracyjnej pomimo art. $9 \mathrm{KPA}$, który ma chronić przed nieznajomością prawa, przy czym ta nieznajomość powinna mieć charakter obiektywny, gdyż w innym przypadku również podmioty profesjonalne mogłyby korzystać

19 Zob. W. Doroszewski (red.), Słownik języka polskiego, https://sjp.pwn.pl/doroszewski/ignorancja;5434212.html [dostęp: 26.02.2018 r.]. 
z jego ochrony, a to naruszałoby już choćby zasadę szybkości postępowania, gdyż wszelkie zaskarżone decyzje kwalifikowałyby się do uchylenia i przekazania sprawy do ponownego rozpoznania. Oczywiście powyższego problemu nie można rozpatrywać jako reguły, ponieważ w dalszym ciągu funkcjonują osoby, które pomimo szerokiego dostępu do informacji nie potrafią należycie prowadzić swoich spraw, stąd też działalność organów wobec takich osób powinna podlegać określonym rygorom.

\section{Podsumowanie}

Znaczenie zasady ignorantia iuris nocet $\mathrm{w}$ polskiej procedurze administracyjnej uzależnione jest od zakresu stosowania zasady informowania stron. Do takich właśnie wniosków prowadzi dotychczasowe orzecznictwo. Stąd też granice paremii ignorantia iuris nocet należy wyznaczać przede wszystkim poprzez rodzaj podmiotu występującego w charakterze strony (innego uczestnika) postępowania. Zasadniczo przyjmuje się, że $\mathrm{w}$ ramach postępowania administracyjnego wyłączone jest obowiązywanie zasady „nieznajomość prawa szkodzi” albo jest ona mocno złagodzona. Istnieją jednak takie przypadki, w których zasada ignorantia iuris nocet w pełni obowiązuje, a wyłączeniu podlega zasada z art. 9 KPA. Wszystko zależy od przygotowania prawniczego strony. Niestety dla organów administracji publicznej brak prawnych przesłanek, które jednoznacznie pozwoliłyby przesądzić o tym, z kim ma do czynienia w ramach konkretnego postępowania. $\mathrm{W}$ związku $\mathrm{z}$ tym trudno im $\mathrm{w}$ ramach stosowania prawa ograniczać obowiązywanie zasady informowania stron, tym bardziej, że muszą one realizować również inne zasady, w szczególności pobudzania zaufania obywateli. Wydaje się w takiej sytuacji, że najprostsze i najbezpieczniejsze dla organów administracji publicznej byłoby zawsze pełne stosowanie art. 9 KPA niezależnie od tego, czy występują w postępowaniu podmioty profesjonalne, czy też nieprofesjonalne. Natomiast pojawia się w tym momencie problem granicy udzielania wszelkich informacji na temat okoliczności prawnych i dawania stronom wskazówek związanych z prawem. $Z$ jednej strony organ ma niejako dbać, a zatem wyprzedzać pewne skutki tak, aby strona postępowania nie poniosła szkody w związku z nieznajomością prawa, ale z drugiej strony nie powinien świadczyć pomocy prawnej i wskazywać stronie sposobu prowadzenia postępowa- 
nia. W sytuacji zatem, jeżeli w postępowaniu występuje podmiot profesjonalny, to on będzie wiedział (a przynajmniej zakłada się, że powinien wiedzieć) jak skorzystać ze wskazówek organu. Natomiast jeśli w ramach tego samego postępowania organ spotyka się z podmiotem nieprofesjonalnym, to te same wskazówki mogą być dla niego niewystarczające. Pojawia się problem, czy organ powinien takiej stronie udzielić szerszych informacji, czy też poprzestać na tych samych co udzielił pomiotowi profesjonalnemu. Niezależnie od tego, którą z opcji wybierze zawsze ulegnie złagodzeniu bądź naruszeniu jakaś inna zasada postępowania - w pierwszym przypadku może to być zasada obiektywizmu, a w drugim zasada czynnego udziału strony w postępowaniu. Niezależnie od powyższego można również postulować, aby de lege ferenda ustawodawca w art. 9 KPA dokonał pewnych zmian redakcyjnych wskazujących wprost na to, że zasada informowania stron ulega złagodzeniu wobec określonych podmiotów. Może to nastąpić na przykład poprzez dodanie sformułowania: „z zastrzeżeniem stron i innych uczestników wykazujących się podstawową znajomością prawa". Oczywiście organ przy pierwszym do niego skierowanym piśmie raczej nie będzie miał możliwości tego zweryfikować, jednak $\mathrm{w}$ takcie postępowania jego wiedza na temat stron będzie większa. Proponowaną zmianę trzeba rozważyć właśnie pod kątem rosnącej świadomości prawnej społeczeństwa i większego dostępu do tego typu informacji. W związku z tym należy rozważyć, czy paremia ignorantia iuris nocet $\mathrm{w}$ obecnych czasach nie nabrała nowego znaczenia, czyli ignorancji wobec prawa jako nieuctwo, w sytuacji, kiedy podstawowa przystępna informacja jest powszechnie dostępna. Właśnie każda osoba należycie dbająca o swoje interesy powinna wykazać co najmniej staranne działanie $\mathrm{w}$ ich realizacji i to niekoniecznie poprzez korzystanie $\mathrm{z}$ usług profesjonalistów. Rozpatrzenia tego zagadnienia nie należy dokonywać pod kątem tego, czy strona rzeczywiście nie znała swoich praw i obowiązków, ale czy mogła je poznać. Bardzo wyraźne jest to w sytuacji kiedy strona w ramach postępowania udaje osobę nieporadną i być może oczekuje na błąd organu, a w chwili zaskarżenia danego aktu wykazuje się nienaganną wiedza, co często wynika ze sposobu formułowania myśli w odwołaniu albo zażaleniu przy jednoczesnym powoływaniu się na przepisy prawne. Warto zwrócić uwagę, że postępowanie administracyjne nie ma charakteru spornego, a zatem oczekiwanie na błąd strony lub organu wydaje się być niedopuszczalne. Nawet w procedurze cywilnej - mającej co do zasady charakter sporny - ustawodawca zabrania tego typu praktyk, które po- 
zwalałyby stronom czekać na błąd przeciwnika i wskazywania istotnych okoliczności dla sprawy na końcu, albo dopiero w postępowaniu odwoławczym. Praktyka sądów powszechnych związana z procedurą cywilną $\mathrm{w}$ zakresie występowania w procesie stron niebędących profesjonalistami, ale wykazującymi się jakąś wiedzą prawnicza, może się okazać przydatna przy ocenie zarówno zasady informowania stron w postępowaniu administracyjnym oraz zakresu zastosowania zasady ignorantia iuris nocet w kontekście nieuctwa. Mianowicie sądy cywilne w sytuacji występowania podmiotów nieprofesjonalnych przy ustanawianiu pełnomocnika z urzędu badają przede wszystkim cechy osobowe wnioskodawcy, w szczególności to, czy jest on w stanie samodzielnie prowadzić swoje sprawy w ramach procesu. Oceny powyższego sąd dokonuje głównie na podstawie wniosku złożonego w tej sprawie i jeżeli strona swoje myśli formułuje precyzyjne, powołuje się na podstawy prawne, to skłania go do wniosku, że jest $\mathrm{w}$ stanie sama występować $\mathrm{w}$ sprawie bez pomocy profesjonalnego pełnomocnika ${ }^{20}$. W związku $\mathrm{z}$ tym może należałoby się zastanowić nad tym również $\mathrm{w}$ kontekście postępowania administracyjnego, co pozwoliłoby organom odstępować $\mathrm{w}$ określonych przypadkach od stosowania zasady z art. $9 \mathrm{KPA}$, a tym samym umożliwiałoby to zastosowanie zasady ignorantia iuris nocet $\mathrm{w}$ tym nowym znaczeniu. Warto zwrócić uwagę, że Kodeks postępowania administracyjnego obowiązuje przeszło pół wieku, a zatem jego założenia znacząco odbiegają od dzisiejszych realiów, na co z pewnością miał wpływ postęp technologiczny. $Z$ tych względów należałoby się zastanowić nad powyższymi zagadnieniami i wypracować takie mechanizmy, które przede wszystkim pozwolą na usprawnienie postępowania administracyjnego, co będzie się z kolei przekładało na szybkość postępowania. Szybkość postępowania natomiast w większości przypadków wpływa na zadowolenie stron postępowania, a tym samym wzrasta zaufanie obywateli do organów administracji publicznej.

$\mathrm{Z}$ powyższego wynika, że zasada ignorantia iuris nocet $\mathrm{w}$ ramach postępowania administracyjnego ma jakieś znaczenie, co powoduje, że nie jest ona całkowicie wyłączona. Takie stanowisko wynika z orzecznictwa sądowo-administracyjnego, które z kolei prowadzi do dalej idących wniosków, czy też wyżej wskazanych postulatów.

Słowa kluczowe: procedura, administracja, zasady, orzecznictwo

${ }^{20}$ Wyrok SA w Krakowie z dnia 29 lipca 2014 r., III AUa 1225/13, LEX 2016. 


\section{Bibliografia}

Duniewska Z., Ignorantia iuris w prawie administracyjnym, Łódź 1998.

Doroszewski W. (red.), Słownik jezyka polskiego, https://sjp.pwn.pl/doroszewski/ignorancja;5434212.html [dostęp: 26.02.2018 r.].

Knysiak-Molczyk H. (red.), Kodeks postępowania administracyjnego. Komentarz, LEX 2016.

Postanowienie WSA w Warszawie z dnia 18 lutego 2016 r., VI SA/Wa 1542/15, LEX 2016.

Wyrok NSA z dnia 16 maja 2012 r., I OSK 699/11, LEX 2016.

Wyrok NSA z dnia 17 czerwca 2011 r., II OSK 1102/10, LEX 2016.

Wyrok NSA z dnia 19 marca 2015 r., II OSK 1985/13, LEX 2016.

Wyrok NSA z dnia 2 marca 2012 r., II OSK 2464/10, LEX 2016.

Wyrok NSA z dnia 20 listopada 2012 r., II OSK 1301/11, LEX 2016.

Wyrok NSA z dnia 4 sierpnia 2016 r., I OSK 2598/14, LEX 2016.

Wyrok SA w Krakowie z dnia 29 lipca 2014 r., III AUa 1225/13, LEX 2016.

Wyrok TK z dnia 12 listopada 2001 r., P 2/01, LEX 2016.

Wyrok WSA w Gliwicach z dnia 29 czerwca 2016 r., IV SA/Gl 1056/15, LEX 2016.

Wyrok WSA w Łodzi z dnia 13 marca 2014 r., III SA/Łd 1306/13, LEX 2016.

Wyrok WSA w Poznaniu z dnia 8 marca 2007 r., IV SA/Po 516/06, LEX 2016.

Wyrok WSA w Warszawie z dnia 18 marca 2013 r., I SA/Wa 2169/12, LEX 2016.

Ustawa z dnia 14 czerwca 1960 r. - Kodeks postępowania administracyjnego,

Dz. U. z 2017 r. poz. 1257 z późn. zm.

\section{THE IMPORTANCE OF THE PRINCIPLE IGNORANTIA IURIS NOCET \\ IN THE POLISH ADMINISTRATIVE PROCEEDINGS. THE EVALUATION OF THE PROBLEM FOR THE CASE-LAW OF THE ADMINISTRATIVE COURT}

\section{S u m m a r y}

The principle ignorantia iuris nocet commonly functions in the Polish legal system, but its meaning is belittled through specific legislation. One such a provision is Article 9 of the Code of Administrative Procedure, expressing the principle of informing the parties, which imposes on the public authorities the duty to make sure that the parties and other participants have not suffered damage because of ignorance of the law. The case-law of administrative courts sets limits on the use of both principles, which means that in a particular case one of them will be of a greater importance. This leads to a slightly different understanding of the maxim ignorantia iuris nocet in the times of wider access to legal information, also in connection with the Polish administrative proceedings.

Key words: the procedure, administration, principles, case law 


\section{ЗНАЧЕНИЕ ПРИНЦИПА IG NOR ANTIA IURIS NOCET \\ В ПОДЬСКОМАДМИНИСТРАТИВНОМ ПОВЕДЕНИИ. \\ ОЦЕНКА ПРОБДЕМЫ ПОДУГ ЯОМ СУДЕБНОАДМИНИСТРАТИВНОГО}

P е 3 ю м е

Принцип ignorantia iuris nocet поверхносно функционирует в польской юридической системе, однако ее значение уменьшается путем конкретные законоположения. Таким положением является ст. 9 Кодекса административной процедуры, который отображает принцип информирования сторон, который накладывает на органы публичной администрации обязанность заботится о том, чтобы стороны, а также другие участники не понесли вред по поводу незнания права. Судебно-административное вынесение решения определяет границы применения как одной, так и другого принципа, что влечет, что в данном случае одна из них будет иметь большее значение. Это ведет к немного другому пониманию выражения ignorantia iuris nocet во временах более широкого доступа к юридической информации, а также в связи с польским административным поведением.

Кдючевые слова: процедура, администрация, принципы, вынесение решения 